\title{
The Enhancement of Teaching-Learning Process Effectiveness through the Development of Instructional Media Based on E-learning of Surabaya's Vocational Student
}

\author{
Puput Wanarti \\ Electrical Engineering Department \\ State Unuversity of Surabaya \\ Surabaya, Indonesia \\ puputwanarti@unesa.ac.id \\ Euis Ismayanti \\ Electrical Engineering Department \\ State Unuversity of Surabaya \\ Surabaya, Indonesia \\ euisheru@gmail.com
}

\author{
Hapsari Peni \\ Electrical Engineering Department \\ State Unuversity of Surabaya \\ Surabaya, Indonesia \\ hapsaripeni@unesa.ac.id \\ Yuni Yamasari \\ Informatic Engineering Department \\ State University of Surabaya \\ Surabaya, Indonesia \\ yamasari2000@yahoo.com
}

\begin{abstract}
In the context of e-learning, many learning theories used in the physical classroom situation, including learning in a community adaptive, collaborative, scaffolding, and scenario learning, have been adopted and validated, The development of instructional media has been built used the adoption of responsive web design techniques developed by the modern web markup language HTML5 and CSS3 style formatting pages while bootstrap frame work was used to build e-learning. A deep analysis of learning effectiveness done in the instructional media based on e learning. The instructional media was applied on vocational high school. Research and Development method was used in this study. The following development procedures were arranged: planning, design, and development phases. In the development phase, on-going evaluation was carried out until a preliminary product was materialized. The result of instructional media based on e-learning development underwent three experimentation phases. In the first experimentation, a media and material experts' validation, were executed. In the second experimentation, through individual experimentation and small group experimentation involving teacher and students (clients) were carried out up to the final phase revision. In the third experimentation, the product validation, also known as summative test, was obtained from extensive field experimentation to discover the effectiveness of the instructional media based on e-learning in a real teaching process using elearning model. This web based e-learning system provided electronic, illustration, group learning, comprehension, and workshop learning units and complied with the training objectives of the designated course. The validation of this model was positive and the results indicated that the proposed web based e-learning course could be further improved by taking into consideration individual learners' attributes.
\end{abstract}

Keywords - component; instructional media: e-learning: HTML5: CS3: bootstrap framework, research and development method: validation.

\section{INTRODUCTION}

The objective of learning, teaching methods, learning materials, of instructional media and evalation become critical element inteaching and learning activities. The selection of teaching method will greatly affect to delivere knowledge. The use of instructional media is one way that can be used by teachers to deliver subject to student . Student will easily understand the subject that will be delivered. Instructional media will greatly assist the effectiveness of a learning process and are also able to raise the motivation and interest of students in learning process. The use of instructional media can also help students improve comprehension, presenting the data to attract, facilitate the interpretation and condense information.

There are several reasons why instructional media can affect students learning process, that is: (1) teaching learning process more attractive to motivate students to learn, (2) the teaching materials will be quite vague so that it can be better understood by students, (3) methods of teaching will be more varied, not only limited to verbal communication through the narrative of words by the teacher and students do not get bored in teaching learning process, (4) students has more learning activities, because not only listen to the description of the teacher, but also other activities such as observing, demonstrating, etc.

Based on the findings of the preliminary field research, the followings can be revealed: 1) teacher has not yet created creative, dynamic, and autonomous learning atmospheres; 2) the students' learning autonomy is still low, and the students are still dependent on the material and the information passed on by the teacher in the learning activity in the class; 3 ) the eleaning model has not been applied by the vocational high school teachers, despite the fact that the ICT infrastructure in the school is quite adequate to support it; 4) teacher has not 
yet utilized e-learning in the learning process; 5) the average score of the Vocational Competency Basics subject is $65<75$, which is still below the minimal learning completeness criteria for (Kriteria Ketuntasan Minimal/KKM) that has been decreed; 6) e-learning has not been applied as it should be, and the teacher only uses power point (offline), because there are no supporting and appropriate media, yet. Those facts mentioned above become good reasons for the development of e-learning media, especially in the Vocational Competency Basics subject in vocational high schools. The development of the e-learning media with regard to the integration of integrated pedagogical aspects becomes an effort to achieve an effective learning process as to improve the learning process which is full of meaning and as to increase the speed of comprehension and creativity, and thus, gaining optimum learning result.

\section{THEORETICAL REVIEW}

A medium as any person, material or event that creates circumstances that put the pupils in a position to acquire knowledge, skills and dispositions [1]. The media that carry messages or information that contains the purposes of teaching, the media is called instructional media. According to Gagne (1970) defines that media are various components in learners' environment which support the learners learn.

There are many aspects of the user experience that can be considered and ways of taking them into account when designing interactive products. Of central importance are the usability, the functionality, the aesthetics, the content, the look and feel, and the sensual and emotional appeal [2]. The media that carry messages or information that contains the purposes of teaching, the media is called instructional media. In order to instructional media actually used for learning, then there are a number of principles that should be considered include: (1) The media used by teachers must be appropriate and directed to achieve the learning objectives, (2) media to be used must be in accordance with the learning materials, (3) Instructional media must be in accordance with the interests and needs of the student condition, (4) media to be used should pay attention to effectiveness and efficiency, (5) the media used be in accordance with teacher's ability to operate.

Three major principles, which could be used as a reference for teachers in selecting instructional media. The description of each principle is as follows: (1) principles of effectiveness and efficiency, (2) principle of relevance, (3) principle productivity [3].

Principe of effectiveness, in the concept of learning, learning effectiveness is success measured by the level of interest exhaustion after the teaching and learning process completed. If all the learning objectives have been achieved then called effective learning. While efficiency is the achievement of learning objectives by using the cost, time, and other resources to a minimum.

Pirnciple or relevance, considerations media conformity with the material that will be presented also need to be considered in selecting instructional media teacher.
Principle of productivity, productifity can be understood in learning achievement optimally with the use of existing resources like human and natural resources. The medium used to generate and achieve goals on learning objectives It will categorized as productive media. The more productive instructional media used the faster and precise learning objectives realized.

Indicators of instructional media can be determined based on the merits of the instructional media. Feasibility of instructional media is comprised of three aspects of validity, practicality, and effectiveness. [4]

Validity, components of teaching materials should be based on basic knowledge (content validity) and all components must be related to one another (validity of construction). If these requirements are fulfilled, the instructional materials can be said to be valid.

Practically, high-quality instructional media that is the end use (teachers and students) consider teaching materials to be used and an easy to use teaching materials through appropriate manner.

Effectiveness, efficacy parameter is the result obtained as expected. In the process of learning that it relates to the learning outcomes of students. Learning effectiveness is measured by the achievement of learners. The achievement of learners in this case is the result of student learning. Student learning outcomes include three terms, namely cognitive, affective, and psychomotor.

E learning unites two main areas, learning and technology [5]. Learning is a cognitive process for achieving knowledge, and technology is an enabler of the learning process, meaning that technology is used like any other tool in the education praxis, as is a pencil or a notebook, for example. Although this seems quite simplistic and logical, a pencil is more technologically transparent tool, and its use may therefore seem more natural to many. Furthermore, technology underpins other problematic situations because it includes various dimensions. E-learning systems aggregate various tools, such as writing technologies, communication technologies, visualization, and storage

E-Learning is defined as all forms of electronic supported learning and teaching, which are procedural in character and aim to effect the construction of knowledge with reference to individual experience, practice and knowledge of the learner. Information and communication systems, whether networked or not, serve as specific media to implement the learning process [6]. E-learning is essentially the computer and network enabled transfer of skills and knowledge. E-learning refers to using electronic applications and processes to learn. E-learning applications and processes include Web-based learning, Computer-based learning, virtual classrooms and digital collaboration. Content is delivered via the Internet, intranet/extranet, audio or video tape, satellite TV, and CDROM. It is used by the educational Institutions to enhance and support the class room teaching and offering courses to a larger population of learners across the Globe. It can be selfpaced or instructor led and includes media in the form of text, image, animation, streaming video and audio. The focus of e 
learning is the learners. They are given the freedom to learn independently, according to their pace and time, therefore giving more autonomy and responsibility to the learners. This could bring to a more interactive and active leaner. Learners will have to plan and prepare thoroughly by searching materials and information regarding a topic with their own initiative. It allows self-learning to happen, revisiting difficult topics repeatedly and most of all allowing learning to happen without embarrassing oneself in front of their colleagues. Questions could be posted on-line [7].

The e-learning systems' theoretical framework contains the three main components of information systems. These components are people, technologies, and services. People interact with e-learning systems. E-learning technologies enable the direct or indirect interaction of the different groups of users. Technologies provide support to integrate content, enable communication, and provide collaboration tools. Elearning services integrate all the activities corresponding to pedagogical models and to instructional strategies. The complex interaction combination is the direct or indirect action with e-learning systems. At the same time, systems provide services according to the specified strategies for activities. In other words, service specifications are e-learning activities aligned with the e-learning pedagogical models and the instructional strategies. With the recent advances in web standards and responsive design techniques it is now possible to provide a progressive, gradually enhanced experience across a wide array of browsers, using one HTML5 markup document and a variety of different Cascading Style Sheets (CSS) [8]. This approach does not selectively deliver content to the user through browser sniffing or server-side device detection, but rather is requested by the mobile browser itself by only rendering the supported web technologies. Mobile devices that fall under the smartphone category currently have superior mobile browsers and support for HTML5 when compared to feature phones.

\section{METHOD}

This research employed a research and development approach, and it was intended to develop the e-learning media for the laws of magnetism on the electrical circuit basic competencies in vocational high schools. The method to be used is the type of research and development methods (research and development (R \& D)). This research and development had produced: (1) e-learning media using responsive web design as its base for the laws of magnetism on the electrical circuit basic competencies learning, (2) tutorial book on how to use e-learning media for the teacher and the student, (3) the laws of magnetism on the electrical circuit basic competencies learning instrument set. The subjects of the experimentation were the students in Grade $\mathrm{X}$, majoring in Audio Video Engineering Program. The subjects of group experimentation were students in State Vocational High School Number 3 of Surabaya. In this research, there are two classes, experimental and control classes. For the experimental class will be given treatment by means of applied learning by using instructional media based on e learning. While the control group was given no treatment. This research uses experimental designs Quasi-Experimental Design (Non-equivalent Control Group Design) because of the difficulty of controlling all the variables that affect the conduct of research, other than that the design was also done to find the effect of an independent variable on the dependent variable in a study.

The data of the research were gathered through primary and supporting instruments. The former was the assessment sheet (questionnaire) for the e-learning product. The questionnaires used were: (1) the questionnaire for the media experts encompassing three aspects namely the aspects of display design, interaction design, and information design; (2) the questionnaire for the material experts including two aspects, namely pedagogical and content correctness; (3) the questionnaire for students and teacher as a product users, in order to get the formative evaluation of the product that had been developed. Their validity and reliability on this research and the development of the e-learning media development were reached in two ways: logical theoretical validity and reliability, obtained by asking for the expert supervisors, material experts, and media experts justification (criticism, suggestion, and revision) on the hints and instrument items that had been composed by the researchers. Those instruments were questionnaire, note sheet, observation guide, and interview guide; The data gathered in this research were: (1) the data of the need analysis of vocational competency basics material and the criteria of hybrid e-learning media; (2) the validation of lesson plan; (3) the validation of the material experts' appraisal; (4) the validation of the media experts' appraisal; (4) the data of accomplished learning; (5) the data of student responses upon applying the e-learning product; The types of the compiled data were the quantitative data using scoring scale as the main data; (6) the appraisal data of the students' evaluation on the e-learning product. The types of the compiled data were the quantitative data using scoring scale as the main data and the qualitative data in the form of suggestion embellishments and written inputs from the respondents as an additional data.

\section{RESUlT AND DISCUSSION}

The result of this research is e-learning media web design using responsive web design. The technique that used for responsive wb design was flexible grid layout, flexible images, and media queries. E-learning media built with responsive web design suported using modern web markup language and CSS3 page style format. The result of e-learning media using responsive web design showed bellow 

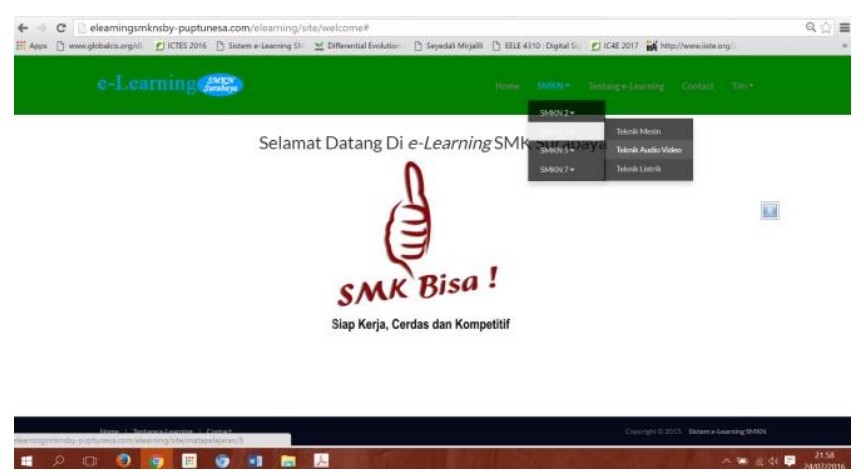

Fig 1. E-learning media on Personal Computer

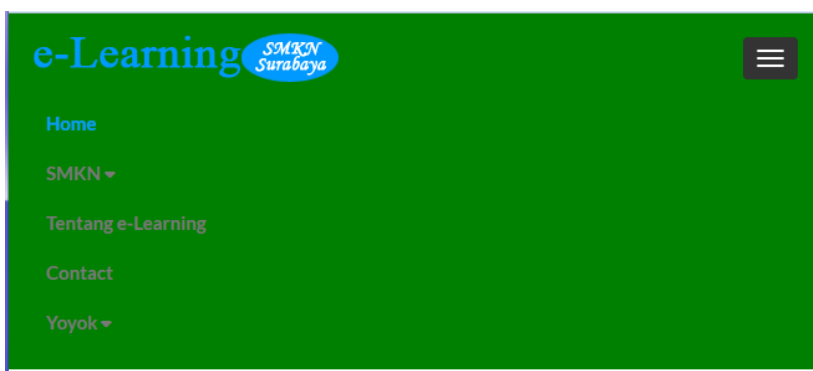

\section{Tingkatan Kelas}

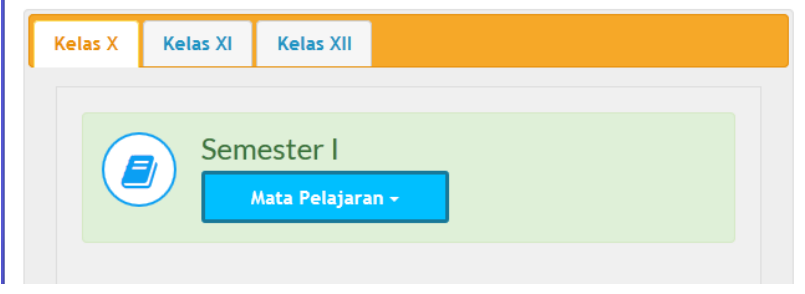

Fig 2. E-learning media on Smart Phone using responsive web design technique.

This study aims to produce instructional media e-learning in Electric Engineering basic competence in applying transformer single phase electrical circuit at Vocational High School number 3 Surabaya. Media validated by media experts and matterial experts. Three aspect developed through media validation; (1) integration of media, (2) balance of media, (3) form of media. The result of media validation total was 87,49 $\%$ with $87,5 \%$ for integration of media, $83,3 \%$ for balance of media and $91,67 \%$ form media.

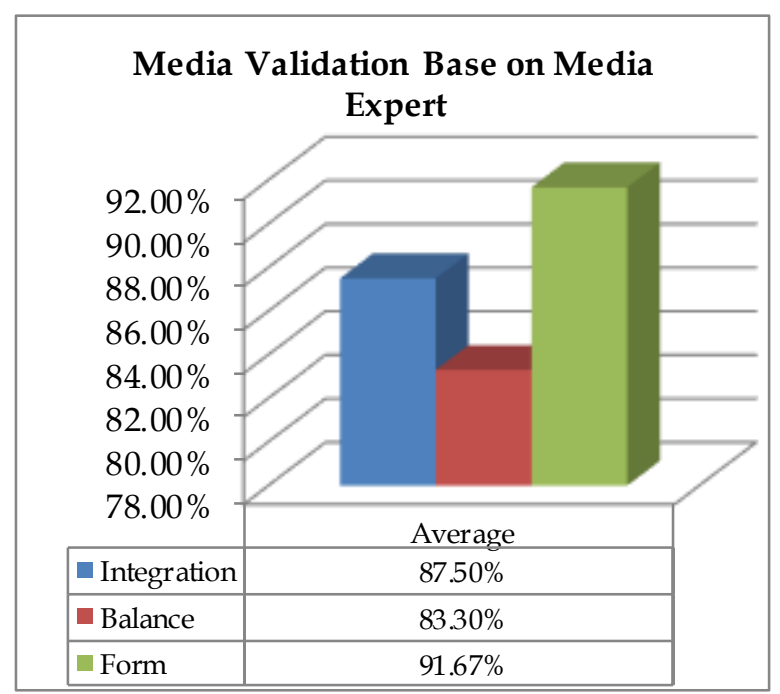

Fig 3. Result of media validation base on media expert

Material expert validation accomplish two aspect that was instructional media format and contain.. The result for instructional media format was $87,5 \%$ and $88,63 \%$ for contain. The avarage validation expert as the graph below

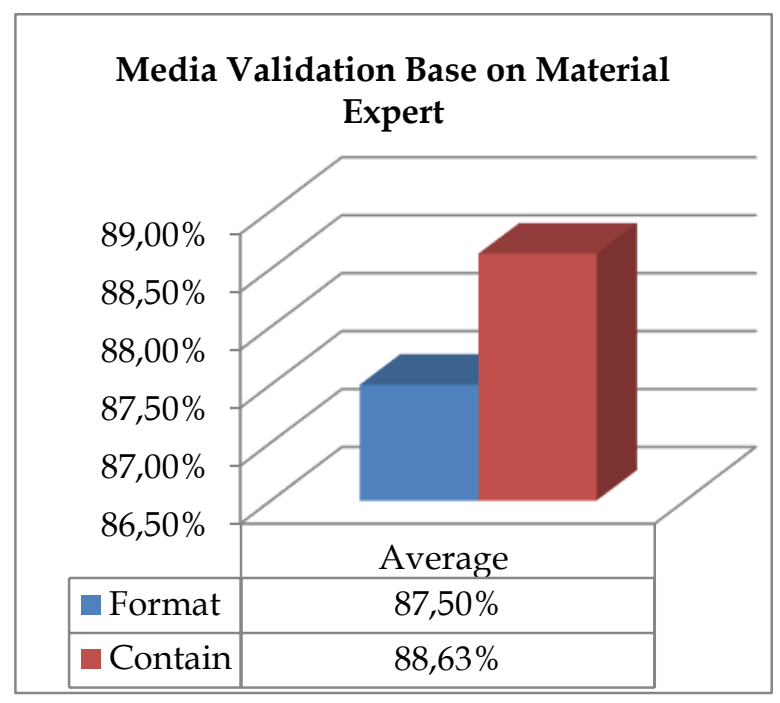

Fig 4. Result of media validation base on material expert

The valiadtion result above show that instructional media that was designed for basic competency in implementing transformer single phase electrical circuit very valid. The instructional media according to subject matter experts with the results of a rating of $88.06 \%$. The experts give a positive respond that this media is very suitable to be applied in vocational high schools. Based on the validation result elaboration from both the media and material experts, it can be concluded that there is no principle mistake, especially those related with the procedure of e-lerning development. It shows that observed from the point of view of development procedure, curriculum, and strategy that is used, the design of 
the product material of the e-learning development is suitable, so that the instructional media product is deemed feasible, acceptable, and in demand, so instructional media based on elearning can be used as instructional media in Vocational High School Number 3 Surabaya.

Thus, the next stage is the field experimentation after the preliminary review as suggested to improve the quality of the e-learning product that will be employed in the learning of vocational competency basics using the e-learning model. The average pre-test score on the experimentation class is 70.81 and the post-test is 83.14 , which shows that there is an average improvement with the Gain Score of 12.33. The fact shows that the students who study vocational competency basics through e-learning media using e-learning model fulfills the standard of minimum criteria of completeness $(\mathrm{KKM})>75$. This means that on experiment class the students have studied thoroughly and the required basic competency has already been reached. Thus, the procedure of the e-learning product development program has taken place as the proposed planning design.

Student responses obtained after instructional media tested for class $\mathrm{X}$ students TAV 3 in Vocational High School Number 3 Surabaya. The following describes a large percentage of the student responses from each aspect and interpretation of responses from the research that has been described previously: (1) In the aspect of media formats included in the category of strongly agree. In the category of strongly agree, the value of getting a percentage of $89.93 \%$ which is interpreted that the students respond very well to media-based learning e-learning. This means that if the media get very good responses, most students are happy to study media format based e learning; (2) In the aspect of media contents included in the category of strongly agree. In the category of strongly agree, the value of getting a percentage of $86.2 \% \%$ interpreted that the students respond very well to the media based learning e-learning. This means that if the media get very good responses, most students are happy for the contents of media-based learning e-learning; (3) in the aspect of the language used in the media included in the category of strongly agree. In the category of strongly agree, the value of getting a percentage of $85.3 \%$, which is interpreted that the students respond very well to media-based learning e-learning. This means that if the media get very good responses, most students are happy to language that is primarily used in mediabased learning e-learning; (4) in the aspect of ease of operation of the media included in the category of strongly agree. In the category of strongly agree, that value gets a percentage of $83.6 \%$, which is interpreted that the students respond very well to the media based learning e-learning. This means that if the media get very good responses, most students are happy to ease of operation based learning media e learning.

From the details of the percentage of these aspects can be concluded, overall students' response to the media get a percentage of $86.25 \%$, which means that the media obtained a very good response, instructional media based on e-learning can be concluded that $86.25 \%$ students are convenient to use instructional media based on e-learning as a instructional media. This is consistent with the definition of learning media according Munadi [9], namely that the learning media is anything that can convey and deliver the message from the source in a planned manner so as to create a conducive learning environment in which the recipient can make the learning process efficient and effective manner.

\section{REFERENCES}

[1] Gerlach, V. S. and Ely, D. P, Teaching and media: a systematic approach. Englewood Cliffs: Prentice-Hall.J. Clerk Maxwell, A Treatise on Electricity and Magnetism, 3rd ed., vol. 2. Oxford: Clarendon, 1892, pp.68-73.

[2] Rogers, Y., Sharp, H. \& Preece, J., Interaction design: beyond humancomputer interaction. 3rd ed. Wiley, United Kingdom., 2011

[3] Musfiqon, Pengembangan Media dan Sumber Pembelajaran. Jakarta: PT Prestasi Pustakarya,2012

[4] Nieven, Nienke, Design Approach and Toolsin Education an Training . Netherlands: SpringerScience Business Media, 1999,

[5] M Aparicio, F Bacao and T Oliveira, An e-Learning Theoretical Framework, Journal of Educational Technology \& Society, 2016,pp 292-307.

[6] P.Nagarajan, W Jiji," ONLINE EDUCATIONAL SYSTEM (elearning)", International Journal of $\mathrm{u}$ - and e- Service, Science and Technology, Vol. 3, No. 4, December, 2010, pp 37

[7] Azwan Abidin and Rozita Nawi. “E-Learning : Penerokaan Media Pembelajaran Terkini" "in online ; 2002 http://www.elearning.unimas.my/Articles/archives/000002.html.

[8] Jason Haag, From eLearning to mLearning: The Effectiveness of Mobile Course Delivery Interservice/Industry Training, Simulation, and Education Conference (I/ITSEC) 2011, 2011 Paper No. 11053 Page 2 of 13

[9] Munadi, Yudhi., Media Pembelajaran, Jakarta: Gaung Persada Press, 2012 